\title{
PURIFIKASI MINYAK GORENG BEKAS DENGAN PROSES ADSORBSI MENGGUNAKAN ARANG KULIT KACANG TANAH (ARACHIS HYPOGAEA L.)
}

\author{
Mardiana dan Tri Santoso \\ Jurusan Pendidikan MIPA \\ Fakultas Keguruan dan Ilmu Pendidikan Universitas Tadulako Palu
}

\begin{abstract}
Absorbents have been widely used in purification of used cooking oil to improve the oil quality. This study aimed to determine the quality of used cooking oil after adsorbed using activated charcoal from peanut shells based on the best purification time in accordance with SNI 01-3741-1995. Oil quality parameters used are color, free fatty acid content, peroxide number, iodine number, water content, and oil density. The best results were obtained at 120 minutes purification time with an absorbance value of $0.023 \mathrm{~A}$, free fatty acid content of $0.22 \%$, peroxide number of $1.83 \mathrm{meq} / \mathrm{kg}$, iodine number of 43.40 , moisture content of $0.19 \%$ and oil density of $0.924 \mathrm{~g} / \mathrm{mL}$ Only iodine number and oil density from the six parametersthat have not yet met the SNI cooking oil quality requirements.
\end{abstract}

Keywords: Used cooking oil, adsorption, peanut shells charcoal, oil quality.

\section{PENDAHULUAN}

Minyak kelapa sawit adalah salah satu bahan utama yang digunakan masyarakat Indonesia sebagai minyak goreng. Minyak goreng merupakan medium pegolahan bahan makanan yang berfungsi sebagai media penggoreng yang sangat penting dalam kehidupan sehari-hari yang kebutuhanya semakin meningkat sehingga menghasilkan limbah yang disebut jelantah yang meningkat pula. Peran minyak goreng pada dasarnya adalah sebagai media perpindahan panas yang efisien untuk meneruskan panas dengan cepat ke permukaan makanan yang digoreng (Maskan \& Bagci, 2003). Pemakaian minyak goreng secara terus menerus pada temperatur tinggi dapat menghasilkan minyak bekas yang tidak layak lagi digunakan karena tidak baik bagi kesehatan sehingga dapat menimbulkan berbagai macam penyakit. Agar minyak jelantah dapat dimanfaatkan kembali, maka perlu dilakukan pengolahan untuk meningkatkan kualitasnya (Nasrun dkk., 2017).

Proses pemurnian minyak jelantah saat ini memang sedang menjadi perhatian banyak pihak, dikarenakan banyaknya aktivitaas industri maupun rumahan yang menghasilkan banyak minyak jelantah yang digunakan secara berulang-ulang. Penggunaan minyak jelantah secara berulangulang dapat mengganggu kesehatan manusia, menimbulkan penyakit kanker, penumpukan asam lemak trans (Trans Fatty Acid/TFA) dalam pembuluh darah, penurunan nilai cerna lemak dan akibat jangka panjangnya dapat mengurangi kecerdasan generasi berikutnya (Fadhilah dkk., 2017)

Penggunaan minyak goreng secara berulangulang dan kontinyu pada proses penggorengan akan mengakibatkan terjadinya reaksi degradasi (hidrolisis, polimerasi dan oksidasi) yang komplek dalam minyak dan menghasilkan berbagai senyawa hasil reaksi sehingga dapat menurunkan kualitas minyak goreng. Kerusakan minyak yang utama adalah karena peristiwa oksidasi yang diakibatkan salah satunya terbentuknya peroksida dan aldehid. Peroksida dan aldehid dapat mempercepat proses timbulnya bau tengik dan flavor yang tidak dikehendaki dalam bahan pangan. Parameter lain untuk menentukan kualitas lemak atau minyak adalah bilangan iod. Bilangan iod adalah bilangan yang menunjukkan banyaknya ikatan rangkap dalam asam lemak (minyak) (Nasrun dkk., 2017).

Salah satu cara yang dapat dilakukan agar minyak jelantah dapat digunakan kembali dalam kehidupan sehari-hari tanpa berpengaruh buruk pada kesehatan yaitu pemurnian (purifikasi). Pemurnian dapat dilakukan dengan metode adsorpsi (Anwar dkk., 2016). Adsorbsi merupakan salah satu metode pemisahan antara suatu bahan dari pengotornya. Metode ini telah sering diterapkan pada berbagai macam proses pemurnian dikarenakan metode yang efisien dan menguntungkan yaitu rancangannya simpel dengan pengoperasian yang mudah dan ekonomis (Miskah dkk., 2019). Proses adsorbsi merupakan proses sorpsi yang menggunakan adsorben yang dalam prosesnya. Adsorben yang digunakan berupa arang aktif. Arang aktif adalah padatan berpori yang mengandung arang $85-95 \%$, diproduksi dengan pemanasan pada suhu tinggi (Buchori dkk., 2018). Arang aktif mampu menyerap anion, kation, dan molekul dalam bentuk senyawa organik dan anorganik berupa larutan dan gas sehingga digunakan sebagai adsorben polutan berkadar rendah pada produkproduk industry (Hidayati dkk., 2016).

Salah satu bahan yang dapat digunakan sebagai adsorben dalam bentuk arang aktif adalah kulit kacang tanah. Salah satu bagian dari kacang tanah yang belum banyak dimanfaatkan adalah kulitnya, saat ini kulit kacang tanah digunakan untuk bahan bakar dan sebagian besar hanya menjadi sampah. Kulit kacang tanah mengandung selulosa $(65,7 \%)$, karbohidrat $(21,2 \%)$, protein $(7,3 \%)$, mineral $(4,5 \%)$, dan lemak $(1,2 \%)$. Kandungan selulosa yang tinggi pada 
kacang tanah dapat dijadikan alternatif dalam pembuatan arang aktif (Irdhawati dkk., 2016).

Beberapa penelitian mengenai proses adsorpsi minyak jelantah yang menggunakan berbagai bahan baku karbon aktif. Seperti telah dilakukan oleh Miskah dkk., (2019), yaitu purifkasi minyak jelantah menggunakan adsorben yang di buat dari kulit durian dengan hasil terbaik pada nilai Asam lemak bebas (Free Fatty Acid/FFA) sebesar 0,0515\%, Sementara itu, Sulistyo dkk., (2016) meneliti kualitas minyak jelantah yang dihasilkan menggunakan karbon aktif dari tempurung kelapa, dimana bilangan peroksida terbaik yaitu sebesar $61,821 \mathrm{~m}^{2} / \mathrm{g}$. Lalu (Yulianti dkk., 2016) melakukan penelitian pemanfaatan batang jagung untuk minyak jelantah. Hasil terbaik yang diperoleh adalah $0,0548 \%$ untuk nilai FFA dan $14,78 \mathrm{Meq} / \mathrm{kg}$ untuk bilangan peroksida. Dari beberapa bahan baku karbon aktif yang telah digunakan, terdapat beberapa kualitas minyak yang belum memenuhi syarat SNI 01-3741-1995.

Tulisan ini dimaksudkan untuk mengkaji seberapa jauh kualitas minyak jelantah hasil purifikasi menggunakn arang aktif kulit kacang tanah.

\section{METODE}

Alat yang digunakan yaitu gelas kimia $100 \mathrm{~mL}$ dan $1000 \mathrm{~mL}$, magnetic stirrer, spatula, batang pengaduk, buret, ayakan 70 mesh, tanur listrik, desikator, erlenmeyer $125 \mathrm{~mL}, 250 \mathrm{~mL}$, dan 1000 $\mathrm{mL}$, pipet tetes, gelas ukur, corong, neraca digital, corong buchner, oven, kertas saring, pompa vakum, karet penghisap, centrifuge, $\mathrm{pH}$ meter, penjepit, cawan porselin, cawan krusibel, corong pisah, neraca analitik, hot plate, statif dan klem, spektrofotometer UV-Vis, lumpang dan alu.

Bahan yang digunakan yaitu minyak goreng yang belum digunakan, minyak jelantah 7 kali penggorengan, kulit kacang tanah, $\mathrm{NaOH} 0,096 \mathrm{~N}$, $\mathrm{NaOH} 15 \%$, indikator phenolptalein, larutan $\mathrm{Na}_{2} \mathrm{~S}_{2} \mathrm{O}_{3} 0,01 \mathrm{~N}$, larutan $\mathrm{Na}_{2} \mathrm{~S}_{2} \mathrm{O}_{3} 0,1 \mathrm{~N}$, larutan KI jenuh, larutan $\mathrm{ZnCl}_{2} 10 \%$, etanol $\left(\mathrm{C}_{2} \mathrm{H}_{2} \mathrm{O}_{5}\right) 96 \%$, asam asetat glacial:kloroform (3:2), larutan amilum $1 \%$, pereaksi iodin bromide.

\section{Penyiapan sampel}

Kulit kacang tanah dicuci dengan air untuk menghilangkan kotoran-kotoran yang menempel pada kulit kacang. Lalu kulit kacang tanah dipotong-potong sampai berukuran kecil, kemudian dikeringkan selama $\mp 5$ hari dengan menggunakan panas sinar matahari.Kulit kacang dikarbonisasi di dalam tanur listrik selama 2 jam dengan suhu pembakaran $400^{\circ} \mathrm{C}$ hingga membentuk arang. Karbon dari kulit kacang tanah selanjutnya didinginkan. Lalu karbon dihaluskan menggunakan lumpang dan alu, kemudian diseragamkan ukurannya menggunakan ayakan 70 mesh (Nurhikmah, 2019).

\section{Proses aktivasi kulit kacang tanah}

Arang kulit kacang tanah diaktivasi dengan 500 $\mathrm{mL}$ larutan $\mathrm{ZnCl}_{2} \quad 10 \%$ dengan cara direndam selama 24 jam, kemudian disaring menggunakan pompa vakum, lalu dimasukkan kedalam cawan krusible dan dipanaskan menggunakan tanur listrik selama 1 jam pada suhu $400^{\circ} \mathrm{C}$, kemudian dicuci menggunakan aquades hingga $\mathrm{pH}$ netral, selanjutnya disaring menggunakan kertas saring dan pompa vakum lalu dikeringkan dalam oven pada suhu $105^{\circ} \mathrm{C}$ selama 1 jam (Maulana dkk., 2017).

\section{Proses pemurniani minyak jelantah \\ Penghilangan bumbu (Despicing)}

Despicing merupakan proses pengendapan dan pemisahan kotoran akibat bumbu dari bahan pangan yang bertujuan untuk menghilangkan partikel halus atau membentuk koloid seperti karbohidrat, garam, gula, dan bumbu rempahrempah yang digunakan menggoreng bahan pangan tanpa mengurangi jumlah asam lemak bebas dalam minyak (Juliana dkk., 2015). Proses despicing dilakukan dengan cara menimbang minyak jelantah sebanyak 500 gram lalu dicampur air dengan komposisi minyak : air (1:1). Campuran minyak dan air dipanaskan hingga volumenya berkurang menjadi setengah dari volume awal. Selanjutnya, lapisan minyak diambil dan diendapkan selama 1 jam menggunakan corong pisah. Setelah itu, lapisan minyak disaring menggunakan kain bersih untuk memisahkan kotoran yang masih tersisa (Dahlan dkk., 2013).

\section{Netralisasi}

Netralisasi adalah proses untuk memisahkan asam lemak bebas dari minyak dengan cara mereaksikan asam lemak bebas dengan basa sehingga membentuk sabun. Minyak jelantah hasil proses despicing sebanyak 400 gram dipanaskan pada suhu $40^{\circ} \mathrm{C}$. Lalu, $\mathrm{NaOH} 15 \%$ sebanyak 20 $\mathrm{mL}$ ditambahkan ke dalam minyak jelantah sambil diaduk selama 10 menit. Kemudian campuran didiamkan selama 10 menit, selanjutnya dipisahkan filtrat dan residunya menggunakan centrifuge (Miskah dkk., 2019).

\section{Adsorpsi minyak jelantah}

Proses adsorpsi adalah proses pemurnian untuk menghilangkan zat-zat warna yang tidak disukai dengan menggunakan adsorben. Adsorben yang digunakan dalam penelitian ini adalah arang aktif kulit kacang tanah. Proses adsorbs minyak dilakukan dengan mencampur minyak goreng hasil netralisasi sebanyak $50 \mathrm{~mL}$ dengan karbon kulit kacang tanah sebanyak 5 gram pada suhu $80^{\circ} \mathrm{C}$ sambil diaduk megunakan magnetic stirrer selama 30 menit, 60 menit, 90 menit, 120 menit, dan 150 menit. Selanjutnya minyak jelantah hasil purifikasi disaring menggunakan kertas saring dan pompa vakum (Dzulhijjah, 2018). 


\section{Analisis kualitas minyak \\ Warna minyak}

Kejernihan atau warna minyak diukur dengan menggunakan Spektrofotometer UV-VIS. Sampel minyak jelantah dimasukkan kedalam kuvet. Setelah itu diukur absorbansinya pada panjang gelombang $422 \mathrm{~nm}$ dengan menggunakan minyak murni yang belum digunakan sebagai blanko. Perlakuan ini dilakukan sebanyak 2 kali (Juliana dkk., 2015).

\section{Penentuan asam lemak bebas (FFA)}

Sebanyak 5 gram minyak jelantah dimasukkan kedalam Erlenmeyer $100 \mathrm{~mL}$. Selanjutnya ditambahkan $25 \mathrm{~mL}$ etanol 95\%, kemudian dipanasakan pada suhu $50-70^{\circ} \mathrm{C}$, selanjutnya ditambahkan indikator PP sebanyak 3 tetes, diaduk selama 30 detik dan dititrasi dengan larutan $\mathrm{NaOH} 0,096 \mathrm{~N}$, titrasi dihentikan jika titran berubah warna menjadi merah mudah yang bertahan tidak kurang dari 30 (Ariani \& Gumai, 2017). Kadar asam lemak bebas dapat ditentukan dengan menggunakan rumus berikut:

$$
\text { Asam lemak bebas }=\frac{\mathrm{V} \times \mathrm{N} \times \mathrm{A}}{\mathrm{m} \times 1000} \times 100 \%
$$

Dimana $\mathrm{V}$ adalah volume $\mathrm{NaOH}$ yang digunakan untuk titrasi $(\mathrm{mL})$; $\mathrm{N}$ adalah Normalitas $\mathrm{NaOH}$; $A$ adalah berat molekul asam laurat; \& $\mathrm{m}$ adalah berat sampel $(\mathrm{g})$

\section{Penentuan bilangan peroksida}

Sebanyak 3 gram minyak jelantah dimasukkan ke dalam erlenmeyer 125 mL.Kemudian ditambahkan $15 \mathrm{~mL}$ larutan asam asetat-kloroform (3:2) dan dikocok sampai bahan terlarut semua. Menambahkan 0,5 ml larutan jenuh $\mathrm{KI}$ dalam erlenmeyer tertutup. Kemudian dibiarkan selama 1 menit sambil digoyang dan menambahkan $15 \mathrm{~mL}$ aquades. Selanjutnya, campuran tersebut dititrasi dengan $\mathrm{Na}_{2} \mathrm{~S}_{2} \mathrm{O}_{3} 0,01 \mathrm{~N}$ sampai warna kuning hampir hilang. Menambahkan 0,5 mL larutan amilum $1 \%$ dan dititrasi kembali sampai warna biru mulai hilang (Barau dkk., 2015). Bilangan peroksida dapat ditentukan dengan menggunakan rumus berikut :

$$
\frac{\mathrm{mL} \mathrm{Na}_{2} \mathrm{~S}_{2} \mathrm{O}_{3} \times \mathrm{N} \mathrm{Na}_{2} \mathrm{~S}_{2} \mathrm{O}_{3} \times 1000}{\text { bobot sampel (gram) }}=\times 100
$$

Dimana $\mathrm{meq} / \mathrm{kg}$ adala Kadar bilangan peroksida; $\mathrm{mL} \mathrm{Na} \mathrm{S}_{2} \mathrm{O}_{3}$ adalah volume titran $\mathrm{Na}_{2} \mathrm{~S}_{2} \mathrm{O}_{3}$; dan $\mathrm{N}$ $\mathrm{Na}_{2} \mathrm{~S}_{2} \mathrm{O}_{3}$ adalah normalitas larutan $\mathrm{Na}_{2} \mathrm{~S}_{2} \mathrm{O}_{3}$

\section{Penentuan bilangan iod}

Sebanyak 0,5 gram minyak ditimbang dan dimasukkan kedalam Erlenmeyer tertutup, selanjutanya ditambahkan $10 \mathrm{~mL}$ kloroform dan 25 $\mathrm{mL}$ pereaksi iodin bromide lalu diletakkan diruang gelap selam 30 menit. Kemudian ditambahkan $10 \mathrm{~mL}$ larutan $\mathrm{KI} 15 \%$ dan aquades yang telah didihkan sebanyak $100 \mathrm{~mL}$. Selanjutnya dititrasi dengan larutan $\mathrm{Na}_{2} \mathrm{~S}_{2} \mathrm{O}_{3} 0,1 \mathrm{~N}$ hingga larutan berwarna kuning pucat. Setelah itu ditambahkan $2 \mathrm{~mL}$ larutan amilum 1\% dan titrasi dilanjutkan hingga warna biru pada larutan hilang (Adhani dkk., 2016). Bilangan iod dapat ditentukan dengan meggunakan rumus berikut :

$$
\text { Bilangan lod }=\frac{\mathrm{v}_{0}-\mathrm{v}_{1} \times \mathrm{N} \mathrm{Na} \mathrm{S}_{2} \mathrm{O}_{3} \times 12,691}{\text { berat sampel }(\text { gram })}
$$

Dimana $\mathrm{V}_{1}$ adalah volume $\mathrm{Na}_{2} \mathrm{~S}_{2} \mathrm{O}_{3}$ untuk Penitran Sampel; $\mathrm{V}_{0}$ adalah volume $\mathrm{Na}_{2} \mathrm{~S}_{2} \mathrm{O}_{3}$ untuk penitran blangko; $\mathrm{N}$ adalah Normalitas $\mathrm{Na}_{2} \mathrm{~S}_{2} \mathrm{O}_{3}$; dan 12,691 adalah bobot atom iodium.

\section{Kadar air}

Krusibel dicuci bersih dan dikeringkan, lalu dipanaskan dalam oven pada suhu $105^{\circ} \mathrm{C}$ selama 1 jam.Selanjutnya didinginkan dalam desikator selama 15 menit. Setelah itu krusibel ditimbang dan dicatat bobotnya. Selanjutnya dimasukkan sampel minyak jelantah sebanyak 1 gram dimasukkan kedalam krusibel lalu, dipanaskan kembali dalam oven pada suhu $105^{\circ} \mathrm{C}$ selama 1 jam, selnjutnya didinginkan dalam desikator selama 15 menit, lalu ditimbang. Diulangi perlakuan yang sama sampai diperoleh bobot yang konstan (Barau dkk., 2015). Kadar air dapat dengan menggunakan rumus berikut :

$$
\text { Kadar air }=\frac{m_{1} m_{2}}{m_{1}} \times 100 \%
$$

Dimana $\mathrm{m}_{1}$ adalah bobot cuplikan (gram); dan $\mathrm{m}_{2}$ adalah bobot cuplikan setelah pengeringan.

\section{Berat jenis}

Piknometer dibersihkan dan dikeringkan, kemudian piknometer ditimbang dan dicatat bobotnya. Selanjutnya sampel minyak jelantah dimasukkan kedalam piknometer. Pengisian dilakukan sampai sampel dalam botol meluap dan tidak ada gelembung udara didalamnya, lalu piknometer dibersihkan dengan tisu. Kemudian ditimbang kembali (Laos dkk., 2016). Berat jenis dapat ditentukan dengan menggunakan persamaan berikut berikut :

$$
\text { Berat Jenis Minyak }=\frac{\mathrm{b}-\mathrm{a}}{\mathrm{v}}
$$

Dimana a adalah berat piknometer kosong (gram); b adalah berat piknometer + sampel minyak (gram); dan v adalah volume piknometer $(\mathrm{mL})$.

\section{HASIL DAN PEMBAHASAN}

Parameter yang diuji untuk menentuan kualitas minyak jelantah adalah warna minyak, bilangan asam lemak bebas, bilangan peroksida, bilangan iod, kadar air, dan berat jenis minyak.

\section{Warna minyak}

Minyak memiliki warna alamiah, yang bersumber dari kelapa sawit itu sendiri. Zat warna pada minyak dapat terekstraksi bersama minyak 
pada proses ekstraksi. Warna alamiah minyak dapat berubah akibat degradasi. Degradasi dapat terjadi pada suhu tinggi dengan kontaminasi dengan bahan atau rempah-rempah dari olahan pangan. Untuk menentukan warna minyak dapat digunakan alat spektrofotometer. Kerusakan senyawa-senyawa dalam minyak memperlihatkan warna minyak semakin gelap dan ditunjukkan dengan meningkatnya nilai serapan (Absorbansi) (Paramitha, 2012). Hasil penentuan nilai absorbansi dengan variasi waktu purifikasi 30,60 , 90, 120 dan 150 menit dapat dilihat pada Gambar 1.

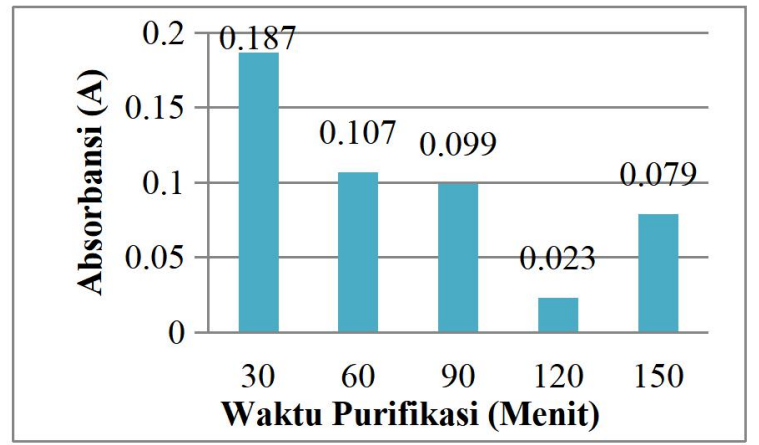

Gambar 1. Pengaruh waktu purifikas terhadap penurunan nilai absorbansi

Berdasarkan hasil yang diperoleh pada Gambar 1. Pada waktu purifikasi 30-120 menit terlihat bahwa terjadi penurunan nilai absorbansi, semakin rendahnya nilai absorbansi menunjukkan warna minyak semakin jernih. Penurunan nilai absorbansi minyak dikarenakan terjadinya proses adsorpsi fisik oleh arang aktif kulit kacang tanah yang tersusun atas pori-pori dengan luas permukaan yang mampu menyerap senyawasenyawa dalam miinyak (Aisyah dkk., 2012). Sedangkan pada waktu purifikasi 150 menit terjadi kenaikan nilai absorbansi pada minyak. Hal ini disebabkan pori-pori arang aktif telah jenuh atau telah tertutup oleh adsorbat sehingga arang aktif tidak mampu lagi menyerap adsorbat atau pengotor-pengotor warna pada minyak jelantah yang mempengaruhi tingkat kejernihannya (Pakiding dkk., 2014).

\section{Kadar asam lemak bebas (FFA)}

Penetuan asam lemak bebas dilakukan dengan metode titrasi asam basa. Prinsip dari titrasi asam basa yaitu analisis jumlah asam lemak bebas dari suatu sampel dengan penambahan larutan basa $(\mathrm{NaOH})$ dalam titrasi yang ditandai dengan berubanya warna sampel menjadi warna merah mudah (Aisyah dkk., 2012). Hasil penentuan asam lemak bebas dengan variasi waktu purifikasi 30 , $60,90,120$ dan 150 menit dapat dilihat pada Gambar 2.

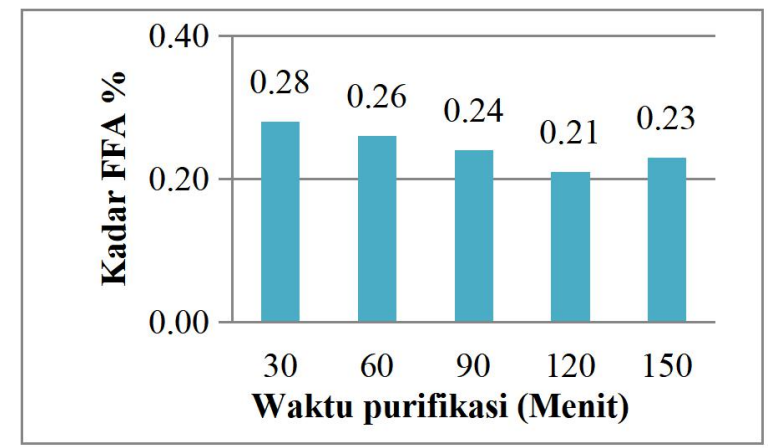

Gambar 2. Pengaruh waktu purifikas terhadap penurunan kadar asam lemak bebas (FFA)

Berdasarkan Gambar 2. dapat dilihat pengaruh waktu adsorpsi terhadap nilai asam lemak bebas yang menunjukkan bahwa waktu adsorpsi arang aktif dengan minyak jelantah dapat menurunkan kadar asam lemak bebas. Pada waktu purifikasi 30-120 menit terjadi penurunan kadar asam lemak bebas. Hal tersebut dapat terjadi karena waktu adsorpsi yang semakin lama sehingga semakin lama terjadinya kontak antara adsorben dan minyak jelantah yang menyebabkan semakin banyak kotoran yang terikat dalam pori-pori arang (Miskah dkk., 2019) menyatakan bahwa waktu kontak yang semakin lama menyebabkan semakin banyak jumlah asam lemak bebas yang diikat oleh permukaan adsorben serta reaksi yang terjadi baik hidrolisa minyak maupun oksidasi asam lemak tidak jenuh dapat berjalan dengan baik. Namun pada waktu kontak 150 menit terjadi penurunan adsorpsi arang aktif terhadap asam lemak bebas, Hal ini disebabkan arang aktif kulit kacang tanah 
sebagai adsorben memilki titik kejenuhan sehingga arang aktif tidak mampu lagi menyerap adsorbat (Talunoe dkk., 2015). Penurunan nilai adsorpsi ini, menunjukkan bahwa arang aktif kulit kacang mengalami desorpsi yaitu melepaskan kembali sampel minyak jelantah. Apabila waktu pengocokan diperpanjang maka arang aktif yang telah menyerap asam lemak bebas secara optimum akan dilepaskan kembali kedalam larutan (minyak jelantah). Hal ini disebabkan arang aktif memiliki kapasitas serapan maksimum dalam menyerap radikal bebas dalam minyak, senyawa peroksida dan asam lemak bebas (Pakiding dkk., 2014).

Data tersebut menunjukkan bahwa kadar asam lemak bebas terendah terdapat pada waktu purifikasi 120 jam yaitu $0,22 \%$. Data tersebut relatif rendah dan sesuai dengan syarat mutu minyak goreng menurut SNI 01-3741-1995, dimana syarat mutu asam lemak bebas minyak goreng adalah maksimal $0,3 \%$.

\section{Bilangan peroksida}

Bilangan peroksida merupakan salah satu nilai untuk menentukan derajat kerusakan pada minyak.lkatan rangkap pada asam tidak jenuh dapat mengikat oksigen sehingga membentuk peroksida yang tidak stabil. Peroksida dapat mengalami reaksi lebih lanjut membentuk aldehid.Selanjutnya aldehid dapat mengalami oksidasi menjadi asam. Jika reaksi-reaksi ini terjadi dapat meningkatkan bilangan peroksida dalam minyak. Bilangan peroksida dapat ditentukan dengan metode lodometri. Data hasil penentuan bilangan peroksida dengan variasi waktu purifikasi 30, 60, 90, 120 dan 150 menit dapat dilihat pada Gambar 3.

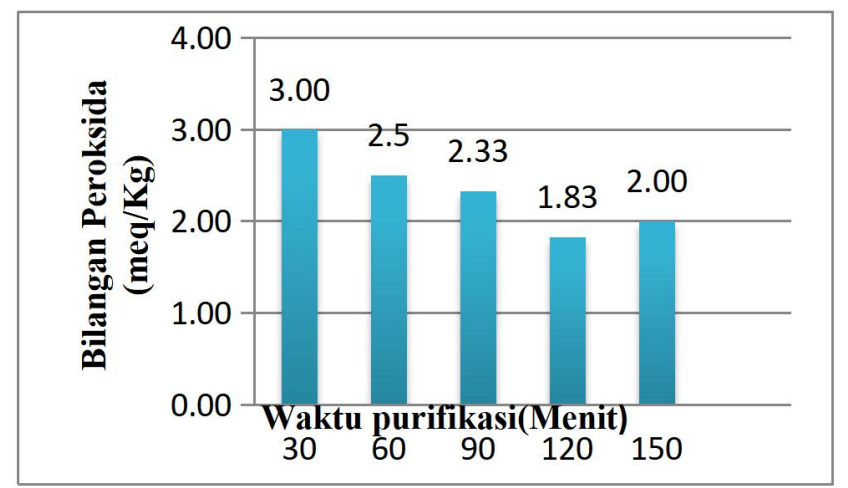

Gambar 3. Pengaruh waktu purifikasi terhadap penuruna bilangan peroksida

Berdasarkan hasil yang diperoleh pada waktu purifikasi 30-120 menit terlihat bahwa terjadi penurunan bilangan peroksida. Hal tersebut dapat terjadi karena waktu adsorpsi yang semakin lama sehinga semakin lama terjadinya kontak antara adsorben dan minyak jelantah yang menyebabkan semakin banyak kotoran yang terikat dalam poripori arang. Namun pada waktu purifikasi 150 menit terjadi penurunan adsorpsi arang aktif terhadap bilangan peroksida. Hal ini disebabkan arang aktif kulit kacang tanah sebagai adsorben memilki titik kejenuhan, sehingga arang aktif tidak mampu lagi menyerap adsorbat (Talunoe dkk., 2015). Penurunan nilai adsorpsi ini, menunjukkan bahwa arang aktif kulit kacang tanah mengalami desorpsi yaitu melepaskan kembali sampel minyak jelantah, apabila waktu pengocokan diperpanjang maka arang aktif yang telah menyerap asam lemak bebas secara optimum akan dilepaskan kembali kedalam larutan (minyak jelantah). Hal ini disebabkan arang aktif memiliki kapasitas serapan maksimum dalam menyerap radikal bebas dalam minyak, senyawa peroksida dan asam lemak bebas (Dzulhijjah, 2018).

Data tersebut menunjukkan bahwa bilangan peroksida terendah terdapat pada waktu purifikasi 120 menit yaitu $1,83 \mathrm{meq} / \mathrm{kg}$. Data tersebut relatif rendah dan sesuai dengan syarat mutu minyak goreng menurut SNI 01-3741-1995, dimana syarat mutu bilangan peroksida maks 2 meq/kg.

\section{Bilangan iod}

Bilangan iod meununjukkan besarnya tingkat ketidakjenuhan asam lemak yang menyusun minyak atau lemak. Besarnya jumlah iod yang diserap menunjukkan banyaknya ikatan rangkap atau ikatan tak jenuhnya yang ada pada minyak lemak (Ketaren, 2008). Semakin tinggi bilangan iod minyak, maka semakin tinggi derajat ketidak jenuhan minyak. Biangan iod dapat ditentukan dengan metode hanus. Data hasil penentuan bilangan peroksida dengan variasi waktu purifikasi 30, 60, 90, 120 dan 150 menit dapat dilihat pada Gambar 4. 


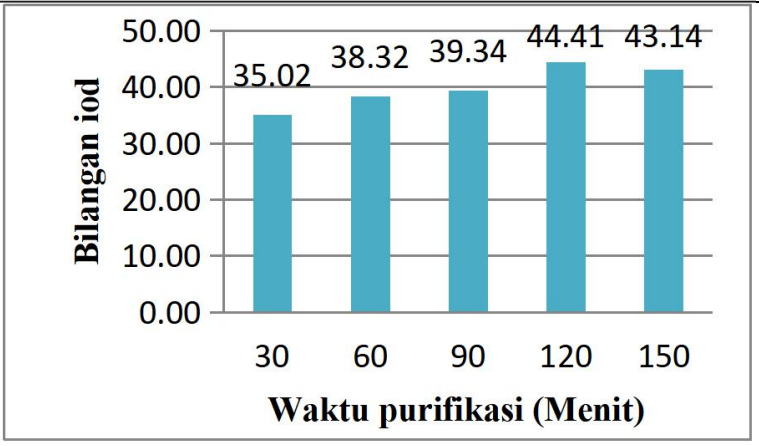

Gambar 4. Pengaruh waktu purifikasi terhadap kenaikan bilangan iod

Berdasarkan Gambar 4 memperlihatkan daya serap terhadap iodin mengalami peningkatan dari waktu 30-120 menit dan selanjutnya mengalami penurunan pada waktu150 menit. Hal ini dikarenakan pada waktu 150 menit tekstur dan pori-pori arang yang terbentuk mengalami kerusakan atau tertutup sehingga tidak dapat lagi menyerap adsorbat.

Data tersebut menunjukkan bahwa bilangan iod terbaik terdapat pada waktu purifikasi 120 menit yaitu 43,40. Data tersebut belum sesuai dengan syarat mutu minyak goreng menurut SNI 01-37411995, dimana syarat mutu bilangan iod sebesar 45-46.

\section{Kadar Air}

Tingginya kadar air dalam minyak dapat diperoleh dari makanan yang digoreng, proses penggorengan, atau kelembaban selama penyimpanan. Selama proses penggorengan, air dalam makanan akan keluar dan diisi dengan minyak goreng sehingga meningkatkan kadar air dalam minyak (Zulkifli dkk., 2018). Data hasil penentuan kadar air minyak jelantah dengan variasi waktu purifikasi $30,60,90,120$ dan 150 menit dapat dilihat pada Gambar 5.

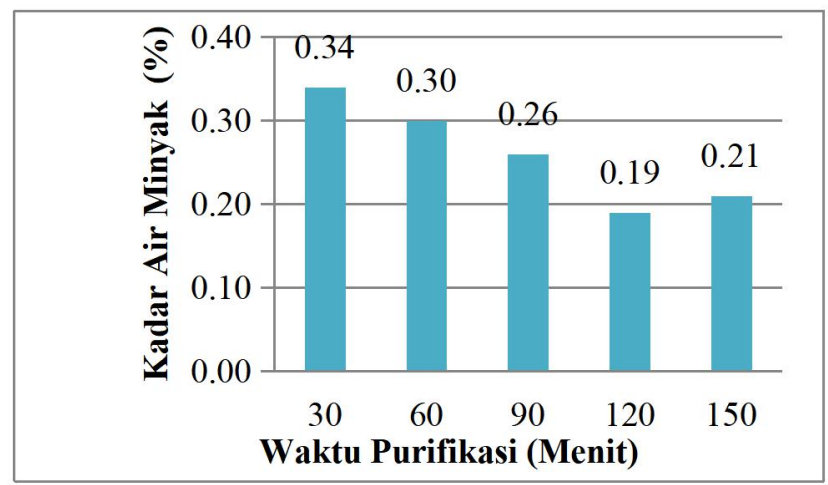

Gambar 5. Pengaruh waktu purifikasi terhadap penurunan kadar air

Berdasarkan Gambar 5 dapat dilihat bahawa pada waktu purifikasi 30-120 menit terjadi penurunan kadar air, hal ini disebakan karena waktu penyerapan juga mempengaruhi penurunan kadar air, semakin lama waktu penyerapan, semakin tinggi penurunan kadar air (Zulkifli dkk., 2018). Namun pada waktu purifikasi 150 menit kadar air minyak naik kembali. Hal ini disebabkan karena waktu kontak dan pemanasan yang terlalu lama sehingga uap air menempel di dinding erlenmeyer yang menyebabkan uap air tersebut jatuh kembali ke minyak (Dzulhijjah, 2018).

Data tersebut menunjukkan bahwa penurunan kadar air terendah terdapat pada waktu purifikasi
120 menit yaitu dengan nilai rata-rata sebesar $0,19 \%$.

\section{Berat jenis}

Berat jenis merupakan salah satu kriteria penting dalam menentukan mutu dan kemurnian minyak. Nilai berat jenis minyak didefinisikan sebagai perbandingan antara berat minyak dengan berat air pada volume air yang sama dengan volume minyak pada yang sama pula (Juliana dkk., 2015). Data hasil penentuan berat jenis dengan variasi waktu purifikasi $30,60,90$, 120 dan 150 menit dapat dilihat pada Gambar 6. 


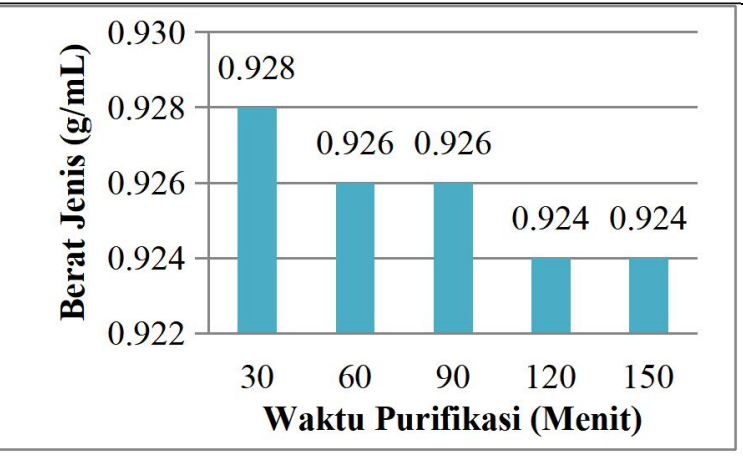

Gambar 6. Pengaruh waktu purifikasi terhadap penurunan berat jenis

Berdasarkan Gambar 6 dapat dilihat bahwa waktu purifikasi mempengaruhi penurunan berat jenis. Pada waktu purifiksi 30-150 menit terlihat bahwa berat jenis minyak mengalami penurunan dimana berat jenis minyak jelantah sebelum adsorbsi yaitu 0,932. Hal ini dikarenakan adsorben dapat mengadsorpsi minyak jelantah dengan baik sehingga impuritis yang terdapat di dalam minyak jelantah menurun dengan cukup banyak, ikatan molekul yang ada di dalam minyak dapat berkurang banyak, serta mampu menghilangkan bau dan warna pada minyak. Selain itu, semakin lama waktu adsorpsi maka penyerapan kotoran pada minyak jelantah semakin tinggi. Penyerapan kotoran ini dipengaruhi oleh suhu pengadukan, dimana proses adsorpsi yang menggunakan suhu tinggi dapat menyebabkan terjadi peningkatan berat jenis. Kadar air yang terdapat pada minyak jelantah setelah proses pemanasan dapat meningkatkan berat molekul minyak jelantah yang juga meningkatkan berat jenis minyak jelantah. Jika terjadi peningkatan berat jenis minyak, maka dikarenakan proses penghilangan kotoran minyak awal yang tidak sempurna sehingga dapat meningkatkan berat jenis minyak tersebut. Penentuan berat jenis dipengaruhi oleh kadar air dan kadar kotoran yang menempel pada minyak (Miskah dkk., 2019).

Data tersebut menunjukkan bahwa penurunan berat jenis terendah terdapat pada waktu purifikasi 120 dan 150 menit, yaitu dengan nilai rata-rata sebesar $0,924 \mathrm{~g} / \mathrm{mL}$. Data tersebut belum sesuai dengan syarat mutu minyak goreng menurut SNI 01-3741-1995, dimana syarat berat jenis minyak goreng adalah maksimal $0,900 \mathrm{~g} / \mathrm{mL}$. Hal ini disebabkan karena masih adanya fraksifraksi berat dalam minyak seperti protein, karbohidrat, garam, gula, rempah-rempah yang telah diadsorpsi (Juliana dkk., 2015)

\section{KESIMPULAN}

Berdasarkan hasil penelitian yang telah dilakukan dapat disimpulkan bahwa terjadi perubahan kualitas minyak jelantah setelah purifikasi menggunakan adsorben arang kulit kacang tanah. Hasil terbaik diperoleh pada waktu purifikasi 120 menit, dengan penurunan nilai absorbansi 0,023 A, kadar FFA 022\%, bilangan peroksida $1,83 \mathrm{meq} / \mathrm{kg}$, bilangan iod 43,40 , kadar air $0,19 \%$, dan berat jenis $0,24 \mathrm{~g} / \mathrm{mL}$. Berdasarkan hasil yang diperoleh dari keenam parameter tersebut hanya bilangan iod dan berat jenis yang belum memenuhi syarat mutu minyak goreng menurut SNI 01-3741-1995.

\section{UCAPAN TERIMA KASIH}

Peneliti mengucapkan terima kasih kepada semua pihak yang telah membantu penelitian ini, khususnya laboran laboratorium kimia FKIP Universitas Tadulako, dan Laboran laboratorium MIPA Universitas Tadulako sehingga penelitian ini dapat berjalan dengan baik.

\section{DAFTAR PUSTAKA}

Adhani, L., Aziz, I., Nurbayti, S., \& Octavia, C. A. (2016). Pembuatan biodiesel dengan cara adsorpsi dan transesterifikasi dari minyak goreng bekas. Jurnal Kimia VALENSi, 2(1), 71-80.

Aisyah, S., Yulianti, E., \& Fasya, A. G. (2012). Penurunan angka peroksida dan asam lemak bebas (FFA) pada proses bleaching minyak goreng bekas oleh karbon aktif polong buah kelor (Moringa Oliefera. Lamk) dengan aktivasi $\mathrm{NaCl}$. Alchemy, 1(2), 53103.

Anwar, R. N., Sunarto, W., \& Ella, K. (2016). Pemanfaatan bentonit teraktivasi asam klorida untuk pengolahan minyak goreng bekas. Indonesian Journal of Chemical Science, 5(3), 189-194.

Ariani, T., \& Gumai, O. putri U. G. (2017). Pengaruh absorben terhadap kualitas fisik minyak. Science and Physics Education Journal (SPEJ), 1(1), 1-6.

Barau, F., Nuryanti, S., \& Pursitasari, D. (2015). Minyak jelantah noni (Morinda citrifolia L .) fruit as adsorbent for cooking oil. J. Akademika Kimia, 4(1), 8-16.

Buchori, L., Ubay, D. L., \& Syahidah, K. (2018). Biodiesel production from waste cooking oil purified with activated charcoal of salak peel. Reaktor, 18(03), 149-154.

Dahlan, H. M., Siregar, H. P., \& Maswardi, Y. (2013). Penggunaan karbon aktif dari biji kelor dapat memurnikan minyak jelantah. Jurnal Teknik Kimia, 19(3), 44-53.

Dzulhijjah, R. (2018). Pemanfaatan limbah kulit 
durian (Duo zibethinus murr) sebagai arang aktif pada minyak jelantah. Skripsi, Palu: Universitas Tadulako.

Fadhilah, R., Kurniasi, E., \& Rayhani, Z. (2017). Performa Bio-adsorben dan karbon aktif dalam proses pemurnian minyak jelantahpada alat prototype portable Bioadsorber. Prosiding SNST Fakultas Teknik, 58-63.

Hidayati, F. C., Masturi, \& Yulianti, I. (2016). Pemurnian Minyak Goreng Bekas Pakai (Jelantah) dengan Menggunakan Arang Bonggol Jagung. JIPF (Jurnal IImu Pendidikan Fisika), 1(2), 67-70.

Irdhawati, I., Andini, A., \& Arsa, M. (2016). Daya serap kulit kacang tanah teraktivasi sam basa dalam menyerap ion fosfat secara bath dengan metode bath. Jurnal Kimia Riset, 1(1), 52-57.

Juliana, I. N., Tandi, S., \& Said, I. (2015). Pemanfaatan buah mengkudu (Morinda Citrifolia L.) sebagai adsorben untuk meningkatkan mutu minyak jelantah. Jurnal Akademika Kimia, 4(4), 181-188.

Ketaren. (2008). Pengantar teknologi minyak dan lemak pangan. Jakatra : UI Press

Laos, L. E., Masturi, M., \& Yulianti, I. (2016). Pengaruh suhu aktivasi terhadap daya serap karbon aktif kulit kemiri. Prosiding Seminar Nasional Fisika (E-Journal), V, 135-139.

Maskan, M., \& Bagci, H. (2003). Effect of different adsorbents on purification of used sunflower seed oil utilized for frying. European Food Research and Technology, 1-4.

Maulana, G. G. R., Agustina, L., \& Susi, S. (2017). Proses Aktivasi Arang Aktif Dari Cangkang Kemiri (Aleurites moluccana) dengan variasi jenis dan konsentrasi aktivator kimia. Ziraa'ah Majalah IImiah Pertanian, 42(3), 247-256.

Miskah, S., Aprianti, T., Agustien, M., Utama, Y., \& Said, M. (2019). Purification of used cooking oil using activated carbon adsorbent from durian peel. IOP Conference Series: Earth and Environmental Science, 396(1).
Nasrun, D., Samangun, T., Iskandar, T., \& Mas'um, Z. (2017). Pemurnian minyak jelantah menggunakan arang aktif dari sekam padi. Jurnal Penelitian Teknik Sipil Dan Teknik Kimia, 1(2), 1-7.

Nurhikmah. (2019). Pemanfaatan arang aktif dari kulit kacang tanah (Arachis hypogaea L) sebagai adsorben kandium (Cd). Skrpisi. Palu: Universitas Tadulako.

Pakiding, L. M., Sumarni, N. K., \& Musafira. (2014). Aktivasi arang tempurung kelapa dengan $\mathrm{ZnCl} 2$ dan aplikasinya dalam pengolahan minyak jelantah. Online Jurnal of Natural Science, 3(1), 47-54.

Paramitha. (2012). Studi kualitas minyak makanan gorengan pada penggunaan minyak goreng berulang. Skrpisi. Fakultas Pertanian Universitas Hasanuddin. Makassar.

Sulistyo, R., Lestari, D., Sari, D. K., Rosmadiana, A., Kimia, J. T., Sultan, U., \& Tirtayasa, A. (2016). Pembuatan dan karakterisasi karbon aktif tempurung kelapa dengan aktivator asam fosfat serta aplikasinya pada pemurnian minyak goreng bekas. Jurnal Teknik Kimia, 12(3), 419-430.

Talunoe, O., Nurhaeni, N., \& Mirzan, M. (2015). Pemanfaatan arang aktif kulit Kacang tanah sebagai adsorben besi (Fe) pada air sumur di desa Pendolo, Kec.Pamona Selatan, Kab. Poso. Kovalen, 1(1), 7-12.

Yulianti, E., Mahmudah, R., \& Royana, I. (2016). Pemanfaatan biosorben batang jagung teraktivasi asam nitrat dan asam sulfat untuk penurunan angka peroksida - asam lemak bebas minyak goreng bekas. Alchemy, 5(1), 10-18.

Zulkifli, Z., Rihayat, T., Suryani, S., Facraniah, F., Habibah, U., Audina, N., Fauzi, T., Nurhanifa, N., Zaimahwati, Z., \& Rosalina, R. (2018). Purification process of jelantah oil using active chorcoal kepok's banana. AIP Conference Proceedings, 20(49). 